\title{
Aoristo)))))
}

International Journal of Phenomenology, Hermeneutics and Metaphysics

\section{Trapaça do maligno... ou trampolim do bem. A limitação humana como vigor da finitude}

\author{
Cheat of the evil... or springboard of the good. Human \\ limitation as a vigour of finitude
}

\author{
Prof. Dr. Enio Paulo Gíachíni \\ FAE Centro Universitário'
}

\section{RESUMO}

O presente texto é uma reflexão informal a partir das contribuições feitas pelo filósofo Hermógenes Harada sobre o tema da limitação humana e sua importância para o crescimento do espírito. Lançase mão também do pensamento de $H$. Rombach para demonstrar o fenômeno da situação-limite humana. Segundo Rombach, há inúmeros elos concêntricos de situações-limite, resguardados por limites, que podem se abrir na medida da disposição de trilhar um caminho de iluminação e transparência da passagem. A trilha humana encontra sentido na medida em que supera situaçõeslimite e transpõe a si, a realidade, seus semelhantes e o mundo a uma dimensão mais elevada de ser. Nesse sentido é importante lançar um olhar analítico para a dificuldade de ver e experimentar a própria dificuldade como um trampolim de elevação.

\section{PALAVRAS-CHAVE}

Ontologia da finitude; Limite; Dimensão; Superação

\section{ABSTRACT}

This text is an informal reflection from the contributions made by the philosopher Hermógenes Harada on the subject of human limitation and its importance for the growth of the spirit. H. Rombach's thinking is also used to demonstrate the phenomenon of the human extreme situation. According to Rombach, there are countless concentric circles of limit situations, guarded by limits, which can open up as far as our willingness to walk a path of illumination and transparency of the passage. The human path finds meaning to the extent that it overcomes limit situations and transposes itself, reality, its fellows and the world to a higher dimension of being. In this sense, it is

\footnotetext{
${ }^{1}$ E-mail: enio.giachini@gmail.com
}

Trapaça do maligno... ou trampolim do bem. A limitação humana como vigor da finitude 


\section{Aoristo)))))}

International Journal of Phenomenology, Hermeneutics and Metaphysics

important to take an analytical look at the difficulty of seeing and experiencing the difficulty itself as a lifting trampoline.

\section{KEYWORDS}

Ontology of finitude; Limit; Dimension; Overcoming

\section{INTRODUÇÃO}

“Os músculos espirituais só se fortalecem carregando o peso da vida (HARADA, 2016, p. 99).

Num dos preciosos pequenos escritos por Harada, intitulado "As dificuldades. Um mal necessário?", encontra-se cunhada a essência de seu modo de trabalhar e pensar: o vigor da finitude. Era o que esse mestre vivia e ensinava. Foi o que ele viveu e ensinou, sua vida de pobreza franciscana. Vemos espelhado em dizeres simples ali que não há nada no homem que não esteja referido intimamente a esse vigor da finitude. Isso é o elementar. Elementar na vida é a repetição e o exercício da frugalidade. Repetir à exaustão o que é o elemento, o mais simples de cada fazer e afazer humano. No jogo de vôlei, é preciso treinar à exaustão o toque de bola. Numa arte marcial o treino principal é a repetição dos elementos simples, até se tornarem uma "segunda" natureza, até serem incorporados em mim, até eu ser incorporado neles, até a arte ser incorporada em mim e nos gestos... até arte, gestos e eu sermos um único movimento vivo e dinâmico.

O elementar é o próprio do humano, não é limitação! Mas é o próprio do humano. A finitude não é algo negativo, é nossa grandeza, nobreza. Não é desgraça, mas nosso privilégio, nossa natureza. São essas afirmações que ficaram, mais que elucubrações e grandes planos filosóficos, teológicos etc. Seguindo esse compasso, mal e porcamente, vamos elaborar uma reflexão sobre a ontologia da finitude. Um nome pomposo para dizer da necessidade de adentrar no circuito da dinâmica das dificuldades humanas. Uma tentativa de análise fenomenológica de alguns poucos aspectos do tema da situação-limite.

O limite na situação humana não é uma parede ou uma cerca, postada como empecilho para o progresso, mas o ponto de resguardo e ponto de partida para encontrar o novo.

\section{SUJEITO-OBJETO}

Um dos caminhos por onde transitava o pensamento do Mestre Harada pode ser chamado de finitude. A palavra, o conceito, o ductus proposto ali é um princípio, 


\section{Aoristo)))))}

\section{International Journal of Phenomenology, Hermeneutics and Metaphysics}

princípio da realidade. Diz que o elementar é o próprio do humano, não é limitação! Mas é o próprio do humano. A finitude não é algo negativo, é nossa grandeza, nobreza. Não é desgraça, mas nosso privilégio, nossa natureza. Parece um martelo inquisitorial, parece um espinho na carne, parece um salário-mínimo o fato de todo dia de novo ter de recomeçar, retomar as rédeas do viver e erguer-se do chão da vida e altear-se no prumo de uma mínima organização. A natureza nossa humana se estrutura de tal modo que provoca sempre de novo e nova nossa co-participação no desfecho de tudo e de todos. Essa "dificuldade" é o pão nosso de cada dia; comerás o pão com o suor do teu rosto.

Em gradações diversas, e com nomenclatura própria, deparamo-nos com cercas de contenção e partilha desses modos e graus de finitude humana: angústia, labor, necessidade, responsabilidade, culpa, dor, sofrimento e morte.

Desespero; angústia; esgotamento impregnado de tédio; não saber, não querer saber mais de nada; intermitente variação de humor desesperado ou eufórico; raiva que não sabe por que e para que e donde vem; ressentimento; ânsia; pressa incontrolável; inflação de preocupação, sempre precipitada, antecipada, fora do lugar; voluntarismo impaciente que faz subir a pressão arterial e aumentar o colesterol ruim etc. (HARADA, 2016, 54)

Harada em suas reflexões foca a necessidade de trabalhar bem a mente para ver o real como ele é, às coisas elas mesmas. A principal dificuldade vem dessa preguiça mental, espiritual. Um dos primeiros e mais ferrenhos nós de estagnação da mente se dá no esquema que herdamos, chamado sujeito-objeto. Esse mesmo esquema faz com que afastemos para o lado de fora de nós toda e qualquer dificuldade. A dor e o sofrimento, o limite não sou eu, não faz parte de mim. Assim, o usual do dia a dia da abordagem do pensamento era repensar a dualidade tão comum sujeito-objeto. Ser homem (sujeito) não é meramente um animal racional, um ser composto de corpo, alma e espírito. A identidade de "sujeito" perpassa um nó de identidades de fundo e identidades superiores, formando uma estrutura de dimensões que precisam ir ganhando unidade e sentido no decorrer do itinerário. De dentro do homem vão aparecendo inúmeras necessidades de conjuntos constelados de necessidades que requerem o trabalho de unificação e sentido. A saúde do corpo como um todo, o exercício físico adequado para a fluidez da vitalidade, o cuidado com a alimentação, a escuta da necessidade de descanso do corpo, as horas de sono; os apelos das ânsias da alma que começar a deixar fluir as necessidades espirituais de fundo etc. Cada membro do corpo é como que um momento do todo do corpo que a seu modo dá uma estruturação completa ao todo do corpo.

$\mathrm{Na}$ direção externa, o homem se vê confrontado igualmente com a tarefa de busca de unificação e sentido. Os elos de estruturação desse a-fazer são por exemplo: busca de companhia, busca de comunidade, familiar, escolar, diversão, comunidade, sociedade, nação, comunidade humana. O que se cunhou como realização humana impele o homem a trabalhar em todos esses setores para encontrar unificação e 


\section{Aoristo)))))}

\section{International Journal of Phenomenology, Hermeneutics and Metaphysics}

sentido, de modo que se vê na premência de a cada vez ir organizando cada constelação dessas como se fosse um núcleo-eu. Esses inúmeros núcleos-eus não são estáticos, fechados, apesar de buscarem identidade, ou justo por isso. Identidade é um conceito dinâmico. O modo de ser próprio de cada situação interior ou exterior do homem é a abertura e transparência. Quando se constrói um tapume de isolamento, fecha-se uma torneira de tramitação de vida. O que não significa que cada momento não tenha sua configuração e consistência, mas que essa solidez de cabana de repouso é sustentada e impingida por esse ducto dinâmico de abertura e passagem para momentos próximos e distantes nas direções do mais externo e do mais interno.

Esses momentos de "constituição" humana, que a tradição chamava de sujeito, pessoa, eu, no vértice de sua manifestação se mostra, via de regra, uma intimação, um apelo, um solavanco provocativo. Nó vértice significa, no calor e no esfogo do momento, na pauleira do dia a dia, não pode não haver essa pauleira de confronto e luta para criar os mecanismos de passagem e iluminação de uma instância para outra. É isso que nos dá canseira, que pode ir criando remansos de ressaibo e refluxo, que vão tomando colorações e tonalidades esverdeadas ao modo do bolor ou do apodrecimento estagnativo de águas paradas, e começar a cheirar mal. Começar a criar azedo e acidez, turvação de olhar e embotamento do ouvir, espasmos de sentir e marasmo no espírito. As cristalizações dessas dificuldades vão ganhando fama e nomes diferenciados, Tdah, Burnout, estresse, depressão, tédio, angústia, tristeza, cansaço, etc. A inércia da estagnação busca potencializar a si mesma, tornando cada vez mais difícil um re-arranque a partir de si mesmo, precisando de uma chupeta da bateria, um empurrão de fora, um solavanco, um auxílio governamental, ou derivados.

Via de regra, ali, o humano lança mão de técnicas. O antídoto que o homem tem encontrado nessa terra dos homens para fazer frente a essa situação são os recursos técnicos, que nos aliviam parte do fardo pesado e nos refrescam um tanto nosso dia a dia. "A técnica é um projeto da existência humana, uma compreensão ontológica fundamental, e quiçá uma que encobre para si a necessidade de um projeto fundamental da existência e a premência de uma compreensão ontológica decisiva" (ROMBACH, 1980, 96). Quando submetidas ao aparato ou ao teor técnico, todas as questões ganham um ar de leveza. Sejam quais questões forem. A técnica é o esforço humano para não fazer esforço. Hoje em dia tem técnica para tudo... Todas as áreas do humano podem ter o auxílio da técnica. Mas será que quem está na ponta originária do desenvolvimento das técnicas detém a melhor solução para o problema abordado? Será que no meio científico hoje há suficiente clarividência para perceber e contemplar a necessidade de transparência e passagem dos inúmeros núcleos-eus, que implicam as dimensões internas e externas do homem, o que implica também toda a realidade, o mundo, os povos e nações com suas histórias, culturas e destinos? Será que posso delegar o destino de tudo que me foi confiado, do dom que recebi e que em mim nasceu, aos cuidados de qualquer instância? Quem entende de saúde são os médicos, quem sabe de governar as nações são os dirigentes; cabe aos técnicos 


\section{Aoristo)))))}

\section{International Journal of Phenomenology, Hermeneutics and Metaphysics}

o desenvolvimento e a provisão de utensílios de comunicação; há que se ouvir os técnicos; nas questões da necessidade de salvação e santidade, precisamos ouvir os especialistas religiosos; os filósofos é que entendem dos processos do pensamento; a alimentação perfeita nos é receitada pelos nutricionistas; se eu tiver dificuldades de comunicação, faço um bom curso de oratória; é importante fazer um bom curso de militância política; doenças psíquicas são tratadas pela psicologia, que já tem tantas áreas talvez quantas são as dificuldades humanas, até psicologia canina já tem. Pra cada dificuldade, há um coach... e pensando bem, o cerco é tão bem feito que tem coach também pra se tornar coach. O controle do controle. Estamos na matrix?

Heinrich Rombach escreveu um livro chamado "Der Ursprung", onde aborda diversos temas relacionados à con-criatividade de homem e natureza. Uma leitura e estudo atento do escrito começa a nos instigar a suspeitar que estamos num caminho já bem avançado no rumo de uma mudança de rumo. Todo esse aparato sistematizado da técnica já está se saturando. A humanidade começa a despertar lentamente de uma sonolência secular. Em todos os povos começa a serem ouvidas vozes e manifestos de um outro ar.

A técnica nos oferece a pílula de um mundo estável. A possibilidade de uso de todas as coisas, todos os recursos e técnicas para solução das dificuldades sem precisar de uma decisão participativa minha, que nos oferece o mundo moderno, também é uma decisão. Uma decisão tomada de olhos fechados e que acontece por trás de nossos olhos. Quem toma essa decisão por mim? Quem decide de antemão o encaminhamento melhor que devem tomar todos os núcleos-eus internos e externos de minha existência? A técnica, ou as técnicas, os coachs nos oferecem um mundo que no fundo já está interpretado e pronto para emprego e uso e, o mais importante, está isento de contrariedades, carrega em seu seio a promessa da não-dificuldade. Eu não vou errar, não preciso correr o risco de me enganar tomando uma decisão. Alguém muito especializado já estudou bem o assunto e preparou um protocolo para que eu possa seguir. É só seguir os protocolos. Nisso há consenso geral, estamos todos unidos, somos todos um. A humanidade precisa confiar no protocolo, as decisões precisam ser técnicas. Não há erro, confie no plano.

Todavia, a natureza, a realidade, a vida, a existência, é renitente, resiliente, tem contornos opacos e obscuros, não se dobra à luz exacerbada, não se permite domar e submeter a padrões prévios, resiste... a esses comandos. Quando nos damos conta... estamos estressados, exaustos, nos suicidamos sem achar ter alcançado unificação e sentido. Ela até, essa tal de realidade, nos tira uma onda e apesar da maquiagem comunicativa, que, nos seus contornos extremos, doura as técnicas com o sabor de pânico ou da folia, para facilitar a deglutição, fica subliminar ou patentemente visível o desatino que as técnicas, por si sós, nos provocam. O homem está só, e sozinho.

Quando temos a coragem de abrir espaço e olhos para ver esse descompasso, logo vem o pensamento geral que é preciso intensificar nossa força de vontade e aprimorar as técnicas para melhor submeter as dificuldades que insistem em se impor e nos desinstalar. 


\section{Aoristo)))))}

International Journal of Phenomenology, Hermeneutics and Metaphysics

\section{DECADÊNCIA}

Decair é igualmente uma forma da vida, uma condição para a mesma. A situação descrita acima em que nos encontramos, de decadência, talvez não possa ser remediada pela simples tomada de decisão individual, pessoal. Seria necessário pensar com profundidade que alcance tem minha decisão pessoal num mundo cada vez mais interligado e globalizado. Será uma questão de mera anuência ou de resistência a essa dominação global? Ou será que isso que percebemos como dominação global não está anunciando um movimento distinto? Seja como for, esse olho de Francisco voltado para dentro e para fora, nos mostra um caminho de observação e cuidado para a implicação em que estamos, cada vez mais intensa, da necessidade de olhar para as implicações as mais profundas, internas, e as mais extensas, para fora. Os conceitos dentro e fora não são espaciais, mas situacionais. São como que ondas de reverberação para dentro e para fora do movimento de vida.

A percepção de decadência e dificuldades com que nos defrontamos, tanto no nosso dia a dia, quanto no macro, nos rumos de nosso conturbado mundo atual, são um malogro (Misslingen), um não chegar a bom termo, uma falha, de certo modo um fracasso. Bem isso. Mas vida é nada mais que movimento de melhorização. E só pode melhorar o que pode malograr. É preciso recuperar-se, reconquistar-se das formas de autoengano e decadência. Além do que a queda, a decadência é uma das formas de vida e um dos estágios do renascimento. A esse movimento planetário de decadência, Heidegger chamou de "a noite do ser"; Hölderlin disse ser a noite dos deuses (Götternacht). (ROMBACH, 1987, p. 80ss) “Porém, mais que o esquecimento do ser, o retraimento dos deuses libera novas forças, que poderão levar a uma forma de relação nova e mais elevada do divino e do humano. Supondo, é claro, que os homens co-participem ativamente dessa guinada, que a história busca realizar". (ROMBACH, 1987, p. 83)

O que se torna importante nessa co-participação (mitmachen)? É provável que esse retraimento do horizonte de sentido chamado ser ou Deus pertença a um processo de autogênese do todo do real. Um processo de ocaso e ressurgimento, como vemos em pequena escala em todo nosso mundo entorno. O movimento de meandro do remanso do rio, a rotina do dia, a morte, um nascimento, o brotar de um caroço de abacate... Essa autogênese convida à coparticipação, cocriatividade. A implicação nossa nessa autogênese se mostra no nível de tensão (Spannung, intensidade) com que adentramos para o externo e o interno. Um nível menor de tensão significa menos diferenciação de interioridade e exterioridade, de modo que o que produz o curso circular de extensão e apropriação é pífio. $\mathrm{O}$ todo se mantém, interno e externo, mas sem definição própria e clara. Há momentos em nossa vida, há espaços em nossa vida social e comunitária que essa tensão é tão fraca que todo o nosso entorno se mostra como que vazio. Estamos rodeados de um mundo material infinito, distante, desligado, sem articulação. Nosso nível de inter-esse é raso e chapado. A indiferença produz o tédio e o desinteresse. O que ainda vemos ao nosso redor são objetos, pessoas-objetos, coisas-objetos, valores-objetos. 


\section{Aoristo)))))}

International Journal of Phenomenology, Hermeneutics and Metaphysics

\section{DO LIMÃO UMA LIMONADA}

O limite, a dificuldade, a crise... podem servir para catapultar a decadência. Também podem servir para criação e co-criação de novos espaços de vida. Pode se abrir a chance de achado de um trend de melhorização. Melhor que o homem perfeito é o homem que se melhora. A perfeição do homem é sua capacidade de melhorar.

Isso se mostra paradigmaticamente no fato de que a imagem do homem que cresce vê um significado bem diferente de "finitude", um significado positivo, fundamental. A finitude não é mais restrição que impede o homem a alcançar toda as grandes metas, mas é o princípio de configuração donde brota um modo próprio de aperfeiçoamento. Ao contrário de ser um empecilho para a realização, a finitude é um pressuposto da mesma. (ROMBACH, 1987, p. 113114)

Significa que é preciso dar um passo, não para fora da situação e não para longe ou para além do homem, mas para além do usual e estagnado. Uma obra de arte que tem sucesso, alcança bom termo, eleva todo o real, inclusive o artista e seu entorno a um nível mais elevado de estruturação, clarificando prospectiva e retrospectivamente a presença de seu universo. Nesse sentido as dificuldades podem implicar uma positividade que eleva o valor da finitude, da falibilidade e da fraqueza humana.

Dentro dessa gênese, a própria culpa pode ser vista como um lugar de elevação para a positividade. A culpa reconhecida é um incitamento para a realização e a elevação. Aqui temos uma fala forte de nosso Mestre Eckhart, no sermão 4, que afirma que Deus tem muito mais prazer em perdoar grandes pecados.

Não há nada que Deus goste de doar com tanto prazer como grandes dádivas. Certa vez, aqui mesmo, disse que Deus até prefere perdoar grandes pecados do que os pequenos. E, quanto maiores, tanto mais os perdoa de bom grado e mais depressa. (ECKHART, 2009, p. 57)

Culpa e pecado parecem estar às voltas com rompimento do interesse pelo que é comum e enrijecimento do interesse no centro particular do ego pequeno. A abrangência negativa do interesse se pode transformar em espaço de vida maior de crescimento. Será por isso que Deus gosta de perdoar pecados grandes?

As situações-limite humanas também não precisam ser os grandes erros, fraquezas, taras, vícios, males e enfermidades múltiplas. Podem ser também pequenas falhas e lapsos típicos como ansiedade, timidez, falta de relacionamento, solidão, inveja etc. A não superação desses limites vai acumulando as presilhas rumo ao sentimento de frustração e fracasso, quando não à indiferença. A situação-limite de cada um é seu muro das lamentações e cada um compõe seu próprio livro das lamentações. As reações que nascem da pura inércia à situação são a salmodia do xingatório ou a ladainha do canto do azar. A fenomenologia da finitude mostra que tal limitação implica uma amarração interna, um fechamento. Esse fechamento da limitação parece desconhecer da possibilidade de transparência e passagem para 


\section{Aoristo)))))}

International Journal of Phenomenology, Hermeneutics and Metaphysics

outras situações, e já não ouve o movimento do apelo de um sentido mais abrangente e mais sonoro.

A existência tende à formação de situações-limite quando entre a força de contração e de alargamento vige um mal-entendido, onde a última tem um desenvolvimento muito fraco para fornecer a soltura de uma situação de efeito fortemente concentrador. (ROMBACH, 1989, p.328-9)

O empenho humano para "vencer" a situação-limite pode ser de pura luta. Nem sempre o enfrentamento é possível. Via de regra falta força. Não há força de vontade hercúlea, heroica, super-homem da vontade de ferro que possa vencer certas situações-limite de nossa vida. Pode ser que a fenomenologia da finitude nos insinue o caminho do vento ou a descida suave da água que vai contornando os empecilhos e mesmo no turbilhão da cachoeira forma uma beleza impar pela comunhão com o entorno. $\mathrm{O}$ enfrentamento não precisa ser luta, pode ser também concorrência, que é mais suave; pode ser também jogo que além de suave é prazeroso. No jogo verdadeiro, o adversário não é inimigo a ser destruído. Muito mais fundamental que a vitória é o bom jogo. Se o inimigo ou adversário for destruído acaba a brincadeira, o jogo acaba. Um grande jogo (Santos 4 X 5 Flamengo) é elogiado e se torna memorável mesmo por quem perde. $\mathrm{O}$ confronto da luta aberta também pode ser prazeroso, quando é fair, honroso e justo.

$\mathrm{Na}$ situação-limite nos sentimos expostos ao perigo de sucumbir. Na medida em que observamos nossa estruturação interna, para dimensões de viver mais largas, e externa, para inte-resses mais comuns, pode se abrir uma passagem de ampliação de vida e interesse que reconquista toda a limitação anterior e emplaca um novo e mais largo sentido de vida.

Essa dinâmica é a próprio processo de vida. Conceitos estagnados de história, vida, eu, objeto, verdade, etc. são cada vez de novo minados pelo vírus da situaçãolimite, que lhe mostra que a força de sustentação de uma situação, de uma região, de uma pessoa, de uma época não vem de sua solidez ontológica prévia, mas de uma coparticipação criativa da realidade e do homem, numa co-criatividade e coatuação, que salva tanto o homem como o ambiente e seu entorno. O mundo também é vivo e propõe caminho de redenção e co-redenção.

Um dos pontos mais estudados do pensamento de Ser e tempo de Heidegger é o conceito do ser-para-a-morte, a situação-limite humana por excelência. Para ele, é só na antecipação do ser-para-a-morte que o Dasein se apropria como ser-para, aquilo que ele tem de ser. Diante do paredão intransponível, intransferível, inadiável e incontornável da morte, o Dasein se vê remetido de volta a antecipar uma decisão de apropriação de todo seu ser-para. Morte é o não-horizonte de todos os horizontes humanos, o aguilhão do fechamento de toda abertura possível da existência, donde se compreende também o conceito de Angst, angústia. Mas na angústia, estreitamento, ainda não se está diante do paredão do nada da morte. A morte não pode ser vivenciada. 


\section{Aoristo)))))}

International Journal of Phenomenology, Hermeneutics and Metaphysics

Esse susto do paredão, quando vem, ricocheteia de volta atingindo o todo da existência e reverbera uma mensagem passível de ser traduzida como proposta de mudança de tonância do ser para o sentido. A consistência de viver não está, parece, em ser, mas em sentido.

\section{O CAMINHO}

A superação das situações-limite não pode ser efetuada simplesmente por uma decisão da vontade, mas pelo achado de um caminho. $\mathrm{O}$ homem sai da situação de dificuldade apenas pelo caminho de um arranque mais elevado, que é a via de uma identificação mais abrangente. A experiência de aviar-se e deixar-se aviar numa travessia de um limite implica risco. De antemão não parece haver nada além do limite. Além do limite que me dificulta a vida há o nada. Achar um caminho nessa escuridão é o mais decisivo. Não é tarefa apenas da vontade, mas de todo o homem, e de todo o seu entorno. Cada limite, por menor que seja, é sempre o momento de passagem do todo. A concentração e escuta, a coragem e ousadia, a resiliência e aguardo por parte do homem e de todo seu entorno pode abrir um avio de caminhada pautado numa espera do inesperado, e dar-se a ultrapassagem para um âmbito mais largo e mais intenso. A experiência da ultrapassagem gera luz e leveza, alegria e êxtase, confirmação e fortalecimento. O itinerário se torna em diálogo de dimensões, conversa de mundos, na linguagem eckhartiana, Gelassenheit.

Caminho é pensado usualmente a partir da meta e define a essa como aquilo que se busca (ou eneka). Assim, a meta é anterior ao caminho e dele independente. Mas o fenômeno do caminho é o deslocar-se rumo ao desconhecido. É o caminho que vai abrir uma nova cercania e abre-a cada vez nova. É a experiência do caminho ou da trilha que abre a paisagem da subida da montanha, do vale vigoroso ou do cerrado. Experimentar fala de sair do perímetro, lançando-se no aberto e desconhecido.

Esse movimento do humano e do real rumo a uma ampliação e a um recolhimento, rumo ao extremo externo e ao mais íntimo, não pode não se defrontar com a experiência do nada, do vazio. O abismo do desconhecido é o que provoca a provocação que vêm de toda situação-limite. No Tao Te King, figura-se esse fenômeno descrevendo que o andar do caminho é proporcionado pelo vazio.

Os trinta raios de uma roda convergem para o cubo, mas é unicamente devido ao espaço vazio que eles são úteis. $\mathrm{O}$ vaso é modelado com argila, mas é unicamente seu espaço vazio que o torna útil. Colocam-se portas e janelas na casa em construção, porém é unicamente por seu espaço vazio que elas são úteis Portanto: o ser, o material, tem sua importância, porém é do não ser, do imaterial, que depende sua verdadeira utilidade. (TAO TE KING apud: ROMBACH, 1971, p. 10 Tradução nossa)

$\mathrm{Na}$ experiência da passagem, seja a menor que for, o nada se anuncia antes, como não-coisa, não definido de antemão, não captável pela força de vontade ou pelo fazer. No mais amplo extremado sentimos a presença do nada como a grande 


\section{Aoristo)))))}

International Journal of Phenomenology, Hermeneutics and Metaphysics

amplidão, imensurável e generosidade de doação de tudo. No mais íntimo e profundo sentimos também o abismo da ignorância, que mergulha e emerge trazendo o novo e carregando para dentro nossas expectativas e receios. $\mathrm{O}$ vazio é o espaço aberto da utilidade. O útil provido pelo vazio é a própria dinâmica de vida. Vida é sempre $a b$ ovo, a partir da gênese de si mesma, do nada. É na experiência dessa ultrapassagem, sobretudo, que experimentamos a serenidade, a leveza de estar sendo carregados no grande fluxo da vida e a confirmação do achado. Há muito nomes para isso. Toda experiência humana da alegria e seus "derivados". Em suma, pode-se chamá-la de êxtase.

\section{0 ÊXTASE}

O movimento ontológico principal dessa experiência de superação de limite é pautado na positividade. O ser, a vida, a realidade, o humano é um processo de melhorização. Estando a caminho, as paragens de mensuração e autocorreção do caminhar apresentam certas marcas. Tudo que se realiza nesse modo a partir da origem traz todas as coisas para um novo e mais amplo nível. Autor, obra, entorno, arte, homem, realidade e mundo são elevados a uma dimensão de superação. Tudo que chega assim a bom termo também pode se chamar de o acontecer, puro e simples. O acontecer pode dar-se de forma mais ou menos intensiva. Dizemos usualmente "a coisa vai". Nosso cumprimento, quando encontramos alguém, contém essa expressão: como vai? Ou simplesmente: Vai? Esse chegar a bom termo "de forma mais ou menos intensa pode também conter e reespelhar o puro acontecer, e esses diversos graus são reproduzidos em nosso linguajar usual por: "vai", "deu certo", "melhor do que o esperado" (es geht, es gelingt, es glückt). No "vai" se dá um acontecer que espelha um desenrolar-se das coisas quase que usual, sem se experimentar a gênese do processo de superação e avanço como tal. No "deu certo", a coisa foi bem-sucedida, chegou a bom termo há a percepção de um conjunto de fatores que convergem para um fim e também a atuação de uma dádiva para que desse certo. No "melhor do que o esperado" há um feliz achado, o resultado é sempre melhor que a encomenda, chega-se a uma situação que supera o que se espera, conferindo nova ontologia ao artista e a sua obra. Abre-se uma nova dimensão que eleva todos os momentos anteriores a uma nova vida. Gradações, não sistematizadas, mas estruturais do acontecer. $O$ acontecer, que sempre unifica momentos perfilados e múltiplos, é um desenlace feliz de uma situação-limite, onde se instaura unificação, leveza e êxtase.

Em cima da sela não há nenhum homem, sobre a sela não há nenhum cavalo... objetivamente é um fato patente e inquestionável que há sobre a sela um homem e sob a sela um cavalo. O cavalgar é tanto mais hábil quanto mais os dois se tornarem um uno indiviso. Só onde homem e cavalo se tornaram um, isto é, não-dualidade... o cavalgar alcança o extremo de sua essência e o mais elevado de sua habilidade"... A arte do arqueiro alcança o máximo de sua essência quando, anteparo, arco, 
International Journal of Phenomenology, Hermeneutics and Metaphysics

seta e disco se unificaram numa única coisa. (HISAMATSU apud: ROMBACH, 1970, p. 70, tradução nossa)

\section{CONSIDERAÇÕES FINAIS}

Essas poucas reflexões querem ser uma meditação, muito aquém do que necessitariam, de gratidão ao Mestre Fr. Hermógenes Harada, por todos os anos de ensino e convivência conosco. Sempre aprendemos com ele a importância de avaliar bem as crises e as dificuldades que se abatiam em nossa vida cotidiana, tanto na organização da vida individual, os cuidados com a saúde, acordar cedo, cuidar do corpo, fazer exercícios, limpar a mente, ter disciplina, chacoalhar o bolor do desânimo e acima de tudo não ligar muito para os achaques dos sentimentos. Não virar sentimental. Na convivência comunitária, nos estudos e na busca espiritual, as dificuldades representavam um trampolim para uma boa massagem da convivência e assim crescer. Temas como a limitação humana, finitude e pobreza nos eram sempre familiares e muito sadios, estimulantes. O texto acima, servindo-se dessa inspiração do Fr. Harada, e das reflexões e estudos de Rombach, segue o mesmo caminho. Aborda-se a situação-limite humana como aguilhão de passagem e oportunidade de transparência e transição para situações mais amplas e ou mais profundas. Vida humana é uma constelação de situações mais próximas e mais distantes, íntimas e mais profundas até "perder-se" no abismo do vazio exterior e interior, donde vem a força de sentido, transformação e crescimento. Mas em cada passagem de situação para outra, por ínfima que seja, se dá essa experiência do vazio, do desconhecido, do abismo, e a alegria, luz e leveza da ressurreição da passagem. Onde em pequenos goles é possível experimentar e co-criar um mundo novo.

\section{REFERÊNCIAS}

ECKHART. Mestre. Sermões alemães. 2a ed. Petrópolis: Vozes, 2009.

HARADA, Frei Hermógenes. O caminho das virtudes. Estudos e reflexões. Florianópolis: Premier, 2004. 2006a.

Coisas, novas e velhas. À margem da espiritualidade franciscana. Bragança Paulista: Edusf,

Em comentando I Fioretti. Reflexões franciscanas intempestivas. 2a ed. Bragança Paulista:

Edusf, 2006b.

. Fragmentos de pensamento Humano-franciscano - I fioreti de Fr. Hermógenes Harada.

Curitiba: Ed. Bom Jesus, 2016.

. Da fidelidade do pensamento. Fragmentos de um diário. Porto Alegre: Evangraf, 2018.

HEIDEGGER, Martin. Ser e tempo. Petrópolis: Vozes, 2006.

ROMBACH, Heinrich. Strukturontologie - Eine Phänomenologie der Freiheit. Freiburg/München, Karl Alber, 1971.

. Die Welt als lebendige Struktur. Probleme und Lösungen der Strukturontologie. Freiburg im Br.: Rombach Verlag, 1980a.

. Phänomenologie des gegenwärtigen Bewusstseins. Freiburg/München, Karl, Alber, 1980b.

. Der Ursprung. Philosophie der Konkreativität von Mensch und Natur. Freiburg im Br.: Rombach

Verlag, 1982.

Trapaça do maligno... ou trampolim do bem. A limitação humana como vigor da finitude 


\section{Aoristo)))))}

International Journal of Phenomenology, Hermeneutics and Metaphysics

_. Strukturanthropologie. "Der menschliche Mensch". Freiburg/München, Karl Alber, 1987.

Submetido: 10 de janeíro de 2021

Aceito: 10 de fevereiro de 2021

Enio Paulo Gíachíni

Toledo, v. 4, n'1 (2021) p. 162-172 